Rozprawy Komisji Językowej ŁTN, t. LXVII, 2019

ISSN 0076-0390; e-ISSN 2450-9310

https://doi.org/10.26485/RKJ/2019/67/2

Viktoriia Cherniak*

\title{
DOM I ZABUDOWANIA GOSPODARSKIE W POLSKIEJ GWARZE WSI WÓJTOWCE NA PODOLU
}

\author{
HOUSE AND FARM BUILDINGS IN POLISH DIALECT \\ IN THE VILLAGE OF WÓJTOWCE IN PODOLIA
}

This article presents five thematic groups connected with the house, farm buildings and its articles in the Polish dialect in the village of Wójtowce. It shows synonymic pairs which consist of native Polish words/common words and Ukrainian and/or Russian borrowings. In addition notes on word formation are provided.

Keywords: Polish dialect, thematic groups, borrowings, synonymic pairs

Słowa kluczowe: gwara polska, grupy tematyczne, zapożyczenia, pary/szeregi synonimiczne

\section{WPROWADZENIE}

Celem artykułu jest pokazanie trwałości polskiej leksyki rodzimej z zakresu słownictwa dotyczącego domu mieszkalnego, zabudowań gospodarskich i ich wyposażenia, a także siły oraz interferencji ukraińskiej i rosyjskiej.

Przedstawione badania opierają się na materiałach zebranych przez Janusza Riegera i jego zespół w latach 1994-1995, Ludmiłę Januszewską w roku 2010 i przeze mnie w roku $2017^{1}$ we wsi Wójtowce. Łącznie dokonano około 30 godzin nagrań od informatorów urodzonych w latach 1911-1952. Materiał zebrano metodą bezpośredniego wywiadu-rozmowy z mieszkańcami, na podstawie Kwestionariusza Janusza Riegera (komputeropis) i kwestionariusza Karola Dejny [1987].

* Uniwersytet Warszawski, Wydział „Artes Liberales”, ul. Krakowskie Przedmieście 26/28, 00-927 Warszawa; e-mail: vika_cherniak@ukr.net.

1 Badania były prowadzone $w$ ramach dofinansowania $z$ dotacji przyznanej przez Ministerstwo Nauki i Szkolnictwa Wyższego Wydziałowi „Artes Liberales” Uniwersytetu Warszawskiego. 


\section{STAN BADAŃ}

Językowo-kulturowy obraz domu przedstawiono już dla języka polskiego [Bartmiński, Bielińska-Gardziel, 2012, s. 9-46], białoruskiego [Kozłowska-Doda, 2015] i łemkowskiego [Misiak, 2015, s. 61-73]. W sposób tradycyjny opisywano leksykę związaną z domem w gwarach polskich na Ukrainie: Genowefa Tymbrowska przedstawiła, w postaci haseł słownikowych, leksykę występującą w polskiej gwarze mieszkańców Czerwonych Chatek. Słownictwo dotyczące grupy tematycznej „Dom i zabudowania gospodarskie” badaczka umieściła w rozdziałach Chatupa, Sprzęty domowe, Podwórze i ogród. Zapożyczenia w słownictwie dotyczącym domu i zabudowań gospodarskich w gwarze Maćkowiec na Podolu przedstawiła Aleksandra Krawczyk [2007, s. 74-75, 77, 81]. O leksyce związanej z gospodarstwem w drobnoszlacheckiej wsi Siaberka na Wołyniu pisała Oksana Zakhutska [2015, s. 131-134].

\section{HISTORIA WSI}

Wójtowce (dziś Pisarówka) to polska wieś chłopska w obwodzie chmielnickim, znajdująca się w odległości 51 km na zachód od Chmielnickiego. W roku 1969 została włączona administracyjnie do ukraińskiej Pisarówki (ukr. Писарівка) [Torczyns'ka, Torczyns'kyj, 2008, s. 374].

Od pierwszego rozbioru Polski (1772 r.) wieś znajdowała się w granicach Imperium Rosyjskiego, później w ZSRR, w strefie przygranicznej. W latach dwudziestych i do połowy trzydziestych w Wójtowcach istniała polska rada wiejska oraz szkoła polska.

Mieszkańcy tej wsi przeżyli kolektywizację, tragedię głodów w latach 1933 i 1947, zesłania do Kazachstanu i na Syberię (według jednego z informatorów zesłano tam około 70-80 rodzin) oraz okupację niemiecką.

W 2017 roku w Wójtowcach mieszkały 1654 osoby. Kościół we wsi został zbudowany na początku lat dziewięćdziesiątych ubiegłego wieku. W 2017 roku msze święte, łącznie z kazaniami, były odprawiane w języku ukraińskim.

We wsi znajduje się szkoła, w której nauka języka polskiego jako obcego zaczyna się od piątej klasy. Lekcje prowadzone są dwa razy w tygodniu. Uczęszczają na nie zarówno Polacy, jak i Ukraińcy.

Informatorzy to osoby bilingwalne: posługują się językiem polskim (gwarą miejscową) i ukraińskim (gwarowym), niektórzy znają też rosyjski. Język polski jest dla nich językiem prymarnym. Według wydzielonych przez Ewę Dzięgiel typów sytuacji bilingwalnych dzisiejszą sytuację języka polskiego we wsi Wójtowce można opisać jako bilingwizm regresywny (zmierzający w kierunku bilingwizmu 
resztkowego). Cechuja go: dominacja języka ukraińskiego w codziennym porozumiewaniu się, kosztem języka polskiego; posługiwanie się językiem polskim w rozmowach między sobą na co dzień przez osoby z najstarszego pokolenia. Widać wyraźny podział międzypokoleniowy [Dzięgiel, 2003, s. 73-75].

Anna Zielińska wyróżnia następujące procesy związane z dwujęzycznością: przełączanie kodów, reguły transpozycji fonetycznych, przenoszenie wzorów. Procesy te mogą być aktywne w różnym stopniu [Zielińska, 2013, s. 232-237]. W mowie mieszkańców wsi Wójtowce też można je wydzielić. Warto odnotować, że sytuacja bilingwalna szybko się zmienia: inaczej wyglądała ona w Wójtowcach na początku XX wieku, a inaczej wygląda dziś.

\section{ZASADY KWALIFIKACJI WYRAZÓW RODZIMYCH I ZAPOŻYCZONYCH}

Zebrany materiał (284 wyrazy) podzieliłam na grupy i podgrupy tematyczne o różnej objętości. Przy wyrazach o nie całkiem jasnym znaczeniu kierowałam się przede wszystkim kontekstem. Przy wyrazach rodzimych nie podaję kwalifikatora, przy wyrazach wspólnych podaję odpowiedni wyraz ukraiński czy rosyjski, przy zapożyczonych piszę, skąd wzięto zapożyczenie. Wyrazy wspólne zaliczam do rodzimych - tak jak Zakhutska [2015] i inni [Krawczyk, 2007], choć są też badacze, którzy odnosząje do zapożyczeń, na przykład Lidija Nepop [2004]. Materiał porównywałam ze Stownikiem języka polskiego Samuela Bogumiła Lindego [SL], Słownikiem języka polskiego pod redakcją Jana Karłowicza, Adama Antoniego Kryńskiego i Władysława Niedźwiedzkiego (tzw. warszawskim) [SW], Stownikiem języka polskiego pod redakcją Witolda Doroszewskiego [SJPD], Stownikiem polszczyzny XVI wieku pod redakcją Marii Mayenowej [SPXVI], Stownikiem gwar małopolskich pod redakcją Jadwigi Wronicz [SGM].

Za źródło zapożyczenia uznaję ten język, z którego wyraz został przejęty bezpośrednio, niezależnie od pierwotnego źródła [por. Walczak, 1982, s. 176; Karaś, 1996, s. 48; Krawczyk, 2007, s. 32; Zakhutska, 2015, s. 13]. Niektóre wyrazy kwalifikuję jako jednoznaczne ukrainizmy lub rusycyzmy tylko wtedy, gdy nie występują one w drugim języku.

Przy wyodrębnianiu zapożyczeń korzystałam przede wszystkim z własnej znajomości języków ukraińskiego i rosyjskiego, a także z następujących słowników: Stownyk ukrajins'koji mowy pod redakcją Iwana Biłodida [SUM], Stowar' ukrajins'koji mowy pod redakcją Borysa Hrinczenki [SHr], Słownyk podil's'kych howirok pod redakcją Dmytra Brylins'kiego [SPH], Tołkowyj słowar' russkogo jazyka pod redakcją Sergeja Ożegowa, Nataliji Szwedowej [TSRJ]. 


\section{OPRACOWANIE MATERIAŁU}

W tabeli 1 przedstawiam liczbę wyrazów w ramach poszczególnych grup i podgrup tematycznych.

TABELA 1. Podział słownictwa na grupy (podgrupy) tematyczne

\begin{tabular}{|c|c|c|c|c|}
\hline $\begin{array}{c}\text { Grupa } \\
\text { tematyczna } \\
\text { (liczba wyrazów) } \\
\end{array}$ & $\begin{array}{c}\text { Podgrupa } \\
\text { tematyczna } \\
\text { (liczba wyrazów) }\end{array}$ & $\begin{array}{c}\text { Liczba } \\
\text { wyrazów } \\
\text { rodzimych }\end{array}$ & $\begin{array}{c}\text { Liczba } \\
\text { wyrazów } \\
\text { wspólnych }\end{array}$ & $\begin{array}{c}\text { Liczba } \\
\text { wyrazów } \\
\text { zapożyczonych }\end{array}$ \\
\hline \multirow{5}{*}{$\begin{array}{l}\text { Określenia domu } \\
\text { i jego elementów } \\
\text { (47) }\end{array}$} & Określenia domu (3) & - & 2 & 1 \\
\hline & Budowa domu (5) & 6 & 5 & 4 \\
\hline & Dach i jego części (10) & 1 & 5 & 4 \\
\hline & $\begin{array}{l}\text { Pomieszczenia } \\
\text { domowe (8) }\end{array}$ & 2 & 2 & 4 \\
\hline & Piec i jego części (11) & 4 & 5 & 2 \\
\hline \multirow{2}{*}{$\begin{array}{l}\text { Sprzęty i wypo- } \\
\text { sażenie domu } \\
(87)\end{array}$} & $\begin{array}{l}\text { Sprzęty i wyposażenie } \\
\text { domu (82) }\end{array}$ & 26 & 30 & 26 \\
\hline & Oświetlenie (5) & 3 & 1 & 1 \\
\hline \multirow{3}{*}{$\begin{array}{l}\text { Zabudowania } \\
\text { gospodarskie } \\
\text { (43) }\end{array}$} & $\begin{array}{l}\text { Określenia } \\
\text { gospodarstwa (2) }\end{array}$ & - & 1 & 1 \\
\hline & $\begin{array}{l}\text { Zabudowania } \\
\text { gospodarskie (32) }\end{array}$ & 8 & 18 & 6 \\
\hline & Ogrodzenia (9) & 3 & 3 & 3 \\
\hline \multicolumn{2}{|c|}{ Sprzęty i narzędzia gospodarskie (46) } & 11 & 25 & 10 \\
\hline \multicolumn{2}{|c|}{$\begin{array}{l}\text { Czynności związane z pracą } \\
\text { w gospodarstwie }(61)\end{array}$} & 26 & 28 & 7 \\
\hline \multicolumn{2}{|c|}{ Razem: $284(100 \%)$} & $90(32 \%)$ & $125(44 \%)$ & $69(24 \%)$ \\
\hline
\end{tabular}

W każdej podgrupie tematycznej wyodrębniłam pary/szeregi synonimiczne ze wskazaniem informatorów, u których one występują. Dla niektórych przykładów podaję szerszy kontekst.

\subsection{Określenia domu i jego elementów}

Grupa tematyczna obejmuje 47 wyrazów: wyrazów rodzimych jest 13, wyrazów wspólnych 19, wyrazów zapożyczonych 15 . W tej grupie wydzielam podgrupy:

1) określenia domu (3): chacina (por. ukr. хатина); chacinka 'zdrobn. od chata' (z ukr. хатинка); chata1 (por. ukr. хата); 
2) budowa domu (15): batka 'belka' (z ukr./ros. балка); bałklon 'balkon' (z ukr./ros. балк'он); drzwi; dwery 'drzwi' (z ukr. dial./pot. двери); dźwirze; fudament (por. ukr. фундамент); futryna; podłoga; próg; przyczołek 'boczna ściana chaty' (por. ukr. причілок); рrzуzba (por. ukr. призьба); rama (por. ukr./ ros. paмa); ramka (por. ukr./ros. pамка); ściana; ścil 'sufit' (z ukr. dial. стіль; por. też pol. dial. ściel);

3) dach i jego części (10): banta 'płatew' (z ukr. бaнma); czerepica 'dachówka' (z ukr. черепиця, ros. черепица; por. też pol. gwar. czerepica); dach (por. ukr. $\partial a x$ ); krokwia 'krokiew: belka w wiązaniu dachowym podtrzymująca pokrycie dachu' (por. ukr. кроквa); łata (por. ukr. лата); okłoty 'snopy słomy, którymi kryje się dach' (por. ukr. околоти); płatwa (por. ukr. платва); strzecha; swołok 'tragarz, belka pod powałą' (z ukr. сволок); szyfier 'szyfer, łupek' (z ukr. pot. шифер, ros. шифер);

4) pomieszczenia domowe (8): chata2 'pokój' (z ukr. pot./dial. xama); góra 'strych'; kładowka 'spiżarnia' (z ros. кладовка); kотіrczyna 'spiżarnia' (z ukr. комірчина); komnata 'izba, pokój' (z ros. комната; por. też SW: komnata); komora 'spiżarnia' (por. ukr. комора); komórka; sieni 'sień' (por. ros. сени);

5) piec i jego części (11): czeryń 'trzon pieca' (z ukr. черінь, ukr. pot. черень); gruba 'piec' (por. ukr. груба); grubka (por. ukr. грубка); kamforka 'palnik, fajerka kuchenna' (por. ukr. dial./pot. камфорка); kотіn (por. ukr. dial. комін); kominek; teżanka 'miejsce do leżenia na piecu' (z ukr. лежанка); ріес²; piecyk; ptyta 'blacha w piecu' (por. ukr. nлит'a); przypiecek 'miejsce wokół pieca, gdzie stawia się garnki'.

Mamy tu 5 par/szeregów synonimicznych, składających się z:

1) wyrazów rodzimych/wspólnych:

- futryna (WG15) - rama (por. ukr./ros. paмa) (WG15), ramka (por. ukr./ ros. рамка) (WG15):

[To w czym okno siedzi, jak się nazywa?] futryna. [„Drzewianne” takie] rama, ramka. $(\mathrm{WG} 15)^{4}$

2) wyrazów rodzimych/wspólnych - zapożyczeń:

- drzwi (WG15), dźwirze (WG15; JF17; MC26; HŁ) - dwery (z ukr. dial./ pot. двери) (H屯);

- komora (por. ukr. комора) (WG15; JF17; JP52) - komórka (JF17) - kładowka (z ros. кладовка) (JF17) - kотігсzуna (z ukr. комірчина) (JF17):

2 W wypowiedziach informatorów występuje w rodzaju męskim.

3 Litery oznaczają imię i nazwisko informatora, a cyfry rok urodzenia.

4 Cytaty podaję w transkrypcji uproszczonej z zachowaniem najważniejszych cech wymowy gwarowej. 
Komora to była wo to jak dzieś wot postrojona chata, to ona tak wo jak dźwiży wot tu siudly - to to chata, a tendy wo na té stroné - to wże kómora. (JF17)

Trzymali takie: miska czy jakie kastrulia, czy jaka posuda taka ǔo, wsio to... to czy monka tam $w$ komorze $\dot{z}$ byta. To wsio $w$ komorze sie trzymało. (WG15)

To baniaki taki je, oni tam stojo w komirczynie. (JF17)

- płatwa (por. ukr. платва) (WG15) - banta (z ukr. банта) (WG15):

To płatwa sie szczyta, dluga, wzdluż chaty. A na te platwe kładli no bałki taki. [A płatwami co nazywali?] banta, banta. (WG15)

3) zapożyczeń:

- chata2 'pokój' (z ukr. pot./dial. xama) (WG15) - klomnata 'izba, pokój' (z ros. к'омната) (WG15):

[A w środku?] jedna chata. Nie byto tych wo przegrodzonych, ni nic. No małe chaty, nie takie ǔo co byli klomnaty, to takie jedna chata była, taj wsio. (WG15)

\subsection{Sprzęty i wyposażenie domu}

Jest to największa grupa, licząca 87 wyrazów. Wśród nich wyrazy rodzime stanowią 29, wspólne 31, zapożyczenia 27.

Wydzieliłam tu wyrazy związane:

1) ze sprzętem i wyposażeniem domu (82): baniaczek; baniak (por. ukr. бан'як); baryłeczka; beczka; boczonek 'mała beczka' (z ukr. бочонок); butel 'butla' (por. ukr. бутель); butelka; ceber (por. ukr. и'ебер); cebryk 'zdrobn. od ceber' (z ukr. цебрик); сеbrzyk; bombetel 'rozkładana sofa' (z ukr. dial. бомбетель); diwan 'sofa' (z ukr. pot. діван, ros. диван); diżka 'dzieżka' (z ukr. діжка); dojniczka (por. ukr. дійничка); duchowka 'duchówka' (por. ukr./ros. духовка); dzbanek (por. ukr. дзбанок); dziższczyna 'mała dzieża' (z ukr. dial./pot. діжчuна); dziżka 'dzieżka' (por. ukr. діжка); flaszka (por. ukr. dial. фляшка); garnek; garnuszek; hładuszczek 'naczynie gliniane bez ucha' (z ukr. dial. әладущик); kaczałka 'wałek do ciasta' (z ukr. качалка); kadubek 'mała beczka' (z ukr. dial./pot. кадубок; por. też SW: kadtubek 'naczynie z kory drzewnej'); kastrula 'garnek' (z ukr. каструля); kastrulka 'garnuszek' (z ukr. каструлька); kieliszek; kociuba 'narzędzie do wygarniania węgli z pieca chlebowego' (por. ukr. коцюб a); kotyska (por. ukr. колиска); kopystka 'drewniana łopatka lub łyżka o długim trzonku' (por. ukr. копистка); krużka 'kubek' (z ukr. dial./pot./ros. кружка); krzesto; kufer 'skrzynia' (por. ukr. dial. кyфep); kwarta 'kubek' (por. ukr. кварma); ławeczka; tawka (por. ukr. лавка); łóżko; lusterko; tyżka; makohon 'stępor, thuczek do stępy' (z ukr. макогон); makutra; miska (por. ukr./ros. миска); miszczyna 'miska' (z ukr. dial. мищина, міщина); miszczynka 'miseczka' (z ukr. dial. міщинка); nary 
'rodzaj tapczanu' (por. ukr. нари, ros. нары); niecki; nożyk (por. ukr. ножик); nóż; patelnia (por. ukr. dial. nательня); pogrzebacz 'narzędzie do poprawiania węgla lub drewna w piecu, w kominie'; pomietło (por. ukr. помел o); posuda 'naczynie' (z ukr. nосудa); pościel 'łóżko' (por. ukr. nocmiль); półeczka; pótka; pótmisek; rondel 'szumówka' (z ukr. dial. рондель); stępa (por. ukr./ros. cmyna); stępka; stopka (por. ukr./ros. стопка); stupka 'zdrobn. od moździerz' (z ukr. ступка); szkaf 'szafa' (z ros. шкаф); szklanka (por. ukr. dial. шклянка); skrzynia (por. ukr. скриня); sofa (por. ukr./ros. соф|a); stolik 'zdrobn. od stół' (z ros. столик); stołeczek; stołek1 'mebel służący do siedzenia'; stołek2 'zdrobn. od stół' (z ukr. столик); stót; szafa (por. ukr. шафa); szafinka 'szafka na naczynia kuchenne' (z ukr. pot. шафінка); taboretka 'taboret, stołek' (por. ukr. табуретка, SGM: 'taboret, stołek'); tapczan (por. ukr. mапчан); tielewizor (por. ukr. телевізор); w'annoczka 'wanienka' (z ukr./ros. в анночка); warzocha; wiadro; witka 'widelec' (z ros. вилка); wywarka 'naczynie, w którym gotują szmacia' (z ukr. в иварка); zbaneczek 'dzbaneczek' (por. ukr. dial./pot. дзб аночок); żarownia 'patelnia' (z ukr. dial. жаровня);

2) z oświetleniem (5): kaganeczek 'zdrobn. od kaganek'; kaganek 'naczynie $\mathrm{z}$ olejem lub naftą do świecenia'; lampa; łampa (z ukr./ros. ламna); łampeczka 'zdrobn. od lampa' (por. ukr. л'ампочка).

Mamy tu 13 par/szeregów synonimicznych, składających się z:

1) wyrazów rodzimych/wspólnych:

- butelka (JF17) - butel 'butla' (por. ukr. бутель) (WG15; JH41) - flaszka (por. ukr. dial. флямка) (WG15; JF17; KB24):

Nie, butel'ka wu nas kazali kiedyś, wsio wremia kazali butel'ka. To tera wo wże tak za... czy, to puślia wojny wże naczeli kazać fliaszka. (JF17)

Butel', butel' taki, wiel'ga fliaszka, duże wiel'ga, butel'. (WG15)

No stodka woda taka, przydaji si z fliaszkami. (KB24)

- kufer (por. ukr. dial. куфер) (MC26) - skrzynia (por. ukr. скриня) (WG15; JF17; MC26; MH32; AW37):

Wíe było to takie, $w$ ważnego maściera sie róbiło toj... toj kufer, to wże taki. U nas nawit' $i$ sze tut wo na chaci jest kufer takij. (MC26)

Skrzynia takla. Takie wo wrodi, zbite wrodi z desèk. I tak jak kryszka przyczépiona. I tak sktadali tam. (MH32)

I skrzyni taki róbili, jak stoty, je taki, ży röbili taki pukaty skrzyni. (JF17) 
- lóżko (JF17; KB24) - nary (por. ukr. нapu, ros. нapb) (JF17) - pościel (por. ukr. постіль) (WG15; JF17; KB24; MH32) - tapczan (por. ukr. тапчан) (WG15; MC26; MH32):

Jak wże nie byto gdzie spać, taj spali na temu tapczanie. (MH32)

Tak koło tèj grubki te nary zbité [...] spi na tych narach. (JF17)

$Z$ drzewa zróbionè drzywiana, drzywiana pościl'. (JF17)

Byli póścieli, wot takie wo drzewniane póścieli byli. Na póścieliach spali. (MH32)

- pogrzebacz 'narzędzie do poprawiania węgla lub drewna w piecu, w kominie' (WG15; JF17) - kociuba 'narzędzie do wygarniania węgli z pieca chlebowego' (por. ukr. коиюба) (WG15; JF17):

Pógrzébacz, to to do pieca byt kiedyś pógrzebacz. Taki, jak palili w piecu kòło garków, to [...] taki drzywianyj patyk o tyj 'o. Tam, szo napali i przysuwali garki tym patykiem. (JF17)

- stołeczek (WG15) - taboretka (por. ukr. табуретка) (MC26):

Na a siadaju wsi koło jednego stołka i każdyn ma stołeczek, takie malieńkie, żeby siadać. (WG15)

2) wyrazów rodzimych/wspólnych - zapożyczeń:

- baryteczka (WG15) - beczka (WG15; JF17; MH32) - dizka (JF17) (z ukr. діжка) - boczonek (JF17) (z ukr. бочонок) - kadubek (JF17) (z ukr. dial./ pot. кадубок) - dziższczyna (JF17) (z ukr. dial./pot. діжчина):

To taki baryłeczki byli z drzewa, taki beczki takie malieńkie. (WG15)

To jedno i to same, my każem dziżka, a to każo beczka na kapuste. Każo tożè beczka, a sze każo dziszczyna. (JF17)

[A beczka to z czego była zrobiona?] z drzewa. (WG15)

No to takij böczonèk, kadubèk, co wino można, i taki, co wogórki można kwasić, kapusty siekać, kadubèk nazywa si. (JF17)

- dzbanek (por. ukr. дзбанок) (JF17) - zbaneczek (por. ukr. dial./pot. дзбаночок) (JF17) - hładuszczek (z ukr. dial. гладущик) (JF17):

[Garnek na mleko?] hładuszczèk i dzbanèk każo. (JF17)

- garnek (WG15; JF17) - kastrula (z ukr. каструля) (WG15; JF17; HG22; LH42) - wywarka (z ukr. в иварка) (JF17; HG22):

A kastrulia, to ma dwie uszków. (WG15)

Tera $w$ wywarce [...] wygotojisz szmacie jak trzeba. (JF17)

- garnuszek (JF17; MH32) - kastrulka (z ukr. каструлька) (JF17); 
- kwarta 'kubek' (por. ukr. кварma) (WG15) - krużka 'kubek' (z ukr. dial./ pot./ros. кружка) (WG15; JF17):

Jakieś krużki, taki kwarty mnieli taki, wode pili, to i teraz taka krużka. (WG15)

- patelnia (por. ukr. dial. пательня) (WG15; JF17) - żarownia (z ukr. dial. жаровня) (WG15; JF17):

U nas wiencèj mówili patel'nia, jak żarownia, a tera wże wsi żarownia. I ja wże każu żarownia. (JF17)

- sofa (por. ukr./ros. coфpa) (JF17) - bombetel 'rozkładana sofa' (z ukr. dial. бомбетель) (JF17) - diwan (z ukr. pot. діван, ros. диван) (JF17):

Bombetèl' to to tutaj bombetèl', co ja każu ta sofa, to to bombetèl'. Jedna pościl' wsiego w chaci byta, wiencyj ni byto, diwanu nijakiego ni byto. (JF17)

- szafa (por. ukr. maфa) (WG15; JF17) - szkaf (z ros. шкаф) (JF17; MC26; MH32; JP52):

Teraz szkafy, a kiedyś te skrzyni dawali. (MH32)

\subsection{Zabudowania gospodarskie}

Grupa tematyczna obejmuje 43 wyrazy, w tym 11 rodzimych, 22 wspólne, 10 zapożyczeń. Wydzielam tu podgrupy:

1) określenia gospodarstwa (2): chadziajstwo 'gospodarstwo' (z ukr. хазяйство); gospodarstwo (por. ukr. господарство);

2) zabudowania gospodarskie (32): chliw 'chlew' (z ukr. хлів); $d$ wór dawn. 'obejście'; jama 'dół do przechowywania ziemniaków' (por. ukr. ямa); kiernica 'studnia' (z ukr. dial. кирниия); klatka; klepisko; kucza 'klatka dla świń' (por. ukr. куча); kurnik (por. ukr. курнци); kuźnia (por. ukr. кузня); letnia kuchnia (por. ukr. літня кухня); loch 'piwnica' (por. ukr. льох); młyn (por. ukr. млин); obejście; ogród; olejnia 'olejarnia' (por. ukr. олійня); pasieka (por. ukr. nасіка, ros. пасека); piwnica (por. ukr. пивниия); pohryb 'piwnica' (z ukr. dial./pot. погриб); sieczkarnia (por. ukr. січкарня); stebnik (por. ukr. dial. стебник); stodoła (por. ukr. стодола); stójło 'miejsce w chlewie, gdzie stoi bydło' (z ukr. стійло, ros. стойло); szopa (por. ukr. шопа); tok (por. ukr. dial./pot. ток); warstat (też warsztat, por. ukr. dial. вapcmam, вapumam); wiatrak; wuli 'ule'; w'ułyky 'ule' (z ukr. в улики); wygon (por. ukr. dial./pot. вигон); zasiek (por. ukr. зlaclik); zastoronek 'miejsce w stodole dla przechowywania' (z ukr. засторонок); żłób; 
3) ogrodzenia (9): firtka 'furtka' (z ukr. dial. фіртка); parkan (por. ukr. паркан); perełlaz 'przełaz' (z ukr. перелlas); ptotek; sztachiety (por. ukr. dial./ pot. umaxєmu); wrota; wrótka; zablor (z ros. заб op); zagroda 'ogrodzenie' (por. ukr. загорода);

Mamy tu $7 \mathrm{par} /$ szeregów synonimicznych, składających się z:

1) wyrazów rodzimych/wspólnych:

- dwór(WG15; JF17, KB24; LH42) - obejście (WG15; JF17; KB24; MS32):

Na obejściu. No na dworze, na dworze, na dwór, na obejściu tak. (WG15)

A obejjście, to wo, to obejjście - chata, dwór. (JF17)

- klatka (WG15; JF17) - kucza (por. ukr. кyчa) (WG15; JF17):

Kucza na dworli. Na zime to wże może i w chliwie być, jak malieńkij paclien..., pać tam, świnka malieńka, to kliatka sie nazywa, taka kucza. Murujo takie na dworze teraz te. Kliatka, kliatka. [A co nazywają „kucza”? Nie nazywają tu kucza nic?] nazywajut'. Świniacza wże, dzie świni, to to. Takło na wid otaka newetyczka taka kucza. [A gdzie ta „kucza” jest na liato?] na obejściu. No na dworze, na dworze, na dwór, na obejściu tak. [Na obejściu, a nie w „chliwie”?] nie, nie, nie. U nas na liato to wsio... Kucza na dwo... na dwori. Na zime to wże może $i$ w chliwie być, jak malieńkij pacilen ... pać tam, świnka malieńka, to kliatka sie nazywa taka kucza. (WG15)

- wiatrak (JF17) - młyn (WG15; JF17; MG31; HŁ) (por. ukr. млин):

Monka - każy-duży dobra była z tego wiatraka. (JF17)

2) wyrazów rodzimych/wspólnych - zapożyczeń:

- gospodarstwo (por. ukr. господарство) (HG22) - chadziajstwo (z ukr. хазяйство) (WG15; KB24; JP52; HŁ):

[A co to jest gospodarstwo?] no chadziajuji, nu gospodarstwo, chata tam, chliw. (HG22)

- piwnica (por. ukr. пивниия) (MG32) - jama (por. ukr. ямa) (WG15; JF17) loch (por. ukr. льох) (WG15; JF17) - pohryb (z ukr. dial./pot. погриб) (WG15; JF17; HG22):

[W czym trzymali barabole zimą?] w plohrybach, a te co na nasieni, to w jame zasypujo. Kopa si jama, zasypi w jame. (JF17)

$\mathrm{Ni}$, ni, takij lioch, taki kopali liochi, kopali jame takie, uktadali, $i$ to takij lioch byt, to to sie nazywa lioch to to baraboli tam, burak. (WG15)

- ptotek(JF17; HG22; MG32) - wrota (WG15; JF17; HG22; KB24) - wrótka (JF17; HG22; KB24) - parkan (por. ukr. паркан) (JF17) - zagroda (por. ukr. загорода) (JF17) - peretlaz (z ukr. перелаз) (HG22; MG32) - zablor (z ros. заб ор) (HG22; LH42): 
To to jak każy: u mnie ży toj ptotèk pólieciat, abo tyj parkan wże pólieciat. (JF17)

Wrota wot jest, że zapieraju obyjście, żeby z drogi nichto nie wijszow. (WG15)

Wrota duże, a małeńki to wrotka, wrotka, wrótka po pol'sku i wrota. (HG22)

No zagrodzony w płotki, to zagroda. (JF17)

- wuli 'ule' (HG22) - w'utyky 'ule' (z ukr. в улики) (HG22).

\subsection{Sprzęty i narzędzia gospodarskie}

Grupa tematyczna liczy 46 wyrazów, w tym wyrazy rodzime stanowią 11, wspólne 25, zapożyczenia 10: brusek 'osełka do ostrzenia kosy' (por. ukr. брусок); сер (por. ukr. dial./pot. uеn); drabina (por. ukr. драбина); drapaka 'drapak'; grabie; grabli 'grabie' (z ukr. граблl); grępla; kierat 'dawne urządzenie do napędu maszyn rolniczych, poruszane przez konie lub woły chodzące w koło'; kirka 'część ostra młotka mularskiego do przecinania cegły'; kombajin (por. ukr. dial./pot. комбаїн); kopatka 'rodzaj łopaty' (z ukr. dial./pot. копалка); koromesto 'koromysło' (por. ukr. кор омисло); kosa (por. ukr. косla); kositka 'kosiarka' (z ros. косилка); koswa 'kosa' (z ukr. dial. косва); topata (por. ukr. лопата); topatka (por. ukr. лопатка); magielnica; maszyna (por. ukr./ros. машина); mietta (por. ukr. мimлla, ros. метл'a); międlica 'narzędzie do międlenia lnu lub konopi'; młóciłka 'młocarnia' (z ros. молотилка); mołotiłka 'młocarnia' (z ros. молотилка); motyka (por. ukr. мотика); płuh 'pług' (z ukr. плуг); podwoda (por. ukr. dial./ pot. подвода); pranik (por. ukr. праник); praska 'żelazko' (por. ukr. праска); reszoto 'przetak' (por. ukr. p'ешето); romanent 'remanent' (por. ukr. реманент); saneczki; sanie (por. ukr. санi); sanki (por. ukr. санкi); sapa 'motyka' (por. ukr. cana); sapak 'motyka' (z ukr. dial. canaк); sapka 'motyka' (z ukr. canкa); siekiera; sierp (por. ukr./ros. cepn); suchowidta 'widły' (z ukr. dial. суховила); szczotka (por. ukr. dial./pot. щотка, ros. щётка); toczydło (por. ukr. точило); trachtor (por. ukr. dial. mрахтор); wozik (por. ukr. возик); wóz; zgrzebło; żarna (por. ukr. жорна).

Mamy tu 3 pary/szeregi synonimiczne, składające się z:

1) wyrazów rodzimych/wspólnych:

- drapaka (JF17; HG22) - mietta (WG15; JF17; HG22) (por. ukr. мimлla, ros. метл'a):

Drapaka wże ta co w chaci si zetrzy, to wynoszu jo na tok zamiatać, tam wże nie trza takij miciuśkiej, jak w chaci. (JF17)

- zgrzebło (JF17) - grępla (JF17) - szczotka (por. ukr. dial./pot. щотка, ros. щётка) (WG15; JF17; MC26):

Gremplia to może być zgrzebło, to co krowe czyścić. (JF17) 
2) wyrazów wspólnych - zapożyczeń:

- motyka (por. ukr. мотика) (JF17) - sapa (por. ukr. cana) (WG15; JF17; HŁ) - sapak (z ukr. dial. сапак) (JF17) - sapka (z ukr. сапка) (JF17):

Wìe birze sapak i sapam. (JF17)

\subsection{Czynności związane $z$ pracą $w$ gospodarstwie}

Grupa tematyczna obejmuje 61 wyrazów (w tym słownictwo dotyczące uprawy roślin - 37 leksemów, które zostało opracowane w artykule Świat roślin w gwarze wsi Wójtowce na tle innych gwar polskich na Ukrainie [Cherniak, w druku]). Wyrazy rodzime stanowią 26 przykładów, wyrazy wspólne 28, zapożyczenia 7: bielić; budować (por. ukr. будувати); chadziajować 'gospodarować' (z ukr. хазяювати); kорас́ (por. ukr. копати); kosić; kropić; międlić; młócić; moczyć (por. ukr. мочити); napalać; naprzaść; narwać (por. ukr. нарвати); nasiać; naszczlepluwać 'naszczepiać' (z ukr. pot./dial. нащ'еплювати); nażać 'nażąć' (por. ukr. нажати); obczyniać 'czyścić buraki z ziemi' (też obczynićs 'obczyścić buraki z ziemi', z ukr. dial./pot. обчиняти/обчинити); obrobić; obszmorgować 'wyrywać, wyciagać' (z ukr. pot. обшм'оргувати); оbżynać (por. ukr. обжинаmu); orać (por. ukr. opamu); parynować 'pierwszy raz orać ściernisko' (z ukr. dial. паринувати); plewić; płukać; pognać (por. ukr. погнати); роobrzynać (por. ukr. пообжинати); posadzić (por. ukr. посадити); posiekać; postawić 'pobudować' (por. ukr. nоставити); pоzbierać (por. ukr. позбирати); prorywać 'przerywać' (z ukr. проривати); rąać; rozsadzać; rozsiewać (por. ukr. pозсіваmu); roztrzaśś́; rwać (por. ukr. pвamu); sadzić; sapać 'gracować, usuwać chwasty' (por. ukr. clanamu); siać; siekać; sinoklos 'koszenie i suszenie traw' (z ukr. dial./ pot. сінокос); skopać (por. ukr. скопати); skosić (por. ukr. скосити); stawić 'budować' (por. ukr. cmlaвитu, ros. pot. ставить); trzymać 'hodować' (por. ukr. тримати); wycierać 'trzeć (na międlicy)'; wyganiać 'wyprowadzić zwierzęta hodowlane z obór na pastwisko' (też wygnać, por. ukr. виганяти, вигнати); wykopać (por. ukr. в икопати); wykosić (por. ukr. в викосити); wymłócić; wyorać (por. ukr. в виорати); wyplewić; wyrabać; wyrwać (por. ukr. в ирватu); wywieść 'wyprowadzić' (por. ukr. в ивести, ros. в вьвести); wуżać (por. ukr. в вжжати, ros. в blжать); zasiewać (por. ukr. засівати, ros. засевать); zbierać (też zebrać); zgartać (por. ukr. згортатu); zmłócić; zrąać; żąć.

\footnotetext{
5 Formy aspektowe, które nie różnią się formą i znaczeniem, traktuję jako jeden wyraz.
} 
Mamy tu 3 pary/szeregi synonimiczne, składające się z:

1) wyrazów wspólnych:

- budować (por. ukr. будувати) (JP52) - postawić (por. ukr. nocmaвити) (WG15; JF17; HB27; MO38; JH41) - stawić (por. ukr. cmaвumu, ros. pot. ставить) (WG15; JF17; ZP22; HB27; MH32; MO38):

Tera doczka si póstawiła tam, na tym óbyściu. (JF17)

2) wyrazów rodzimych/wspólnych - zapożyczeń:

- orać (JF17) (por. ukr. opamu) - parynować (JF17) (z ukr. dial. napuнyвати);

3) zapożyczeń:

- prorywać 'przerywać' (NM1) (z ukr. проривати) - obszmorgować 'wyrywać, wyciagać' (z ukr. pot. обшм оргувати) (HG22):

Tu buraki obszmórguju. No dostyhnut' i obszmurguju sie ryńkami tymi. (HG22)

\section{UWAGI O SLOWOTWÓRSTWIE}

Charakterystyczną cechą zebranych wyrazów jest użycie wyrazów zdrobnialych, które utworzono za pomocą sufiksów: $-\boldsymbol{e} \boldsymbol{k}^{6}$ : baniaczek ( $\leftarrow$ baniak), brusek ( $\leftarrow$ brus), dzbanek $(\leftarrow$ dzban), kadubek $(\leftarrow$ kadub 'beczka'), kaganeczek ( $\leftarrow$ kaganek), kaganek $(\leftarrow$ kaganiec), kieliszek ( $\leftarrow$ kielich), kominek $(\leftarrow$ komin $)$, ptotek $(\leftarrow$ plot $)$, stoleczek $(\leftarrow$ stotek), stotek $2(\leftarrow$ stót), zbaneczek $(\leftarrow$ zbanek);

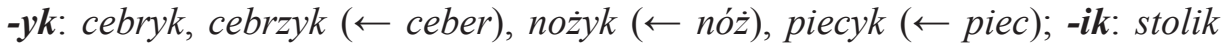

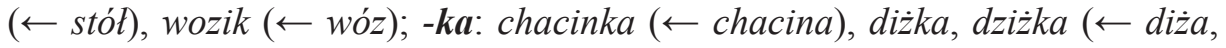
dziża), grubka $(\leftarrow$ gruba), kastrulka $(\leftarrow$ kastrula), komórka $(\leftarrow$ komora), topatka $(\leftarrow$ topata), miszczynka $(\leftarrow$ miszczyna), póteczka $(\leftarrow$ pótka $)$, ramka $(\leftarrow$ rama $)$, sapka $(\leftarrow$ sapa $)$, stępka $(\leftarrow$ stępa), stupka $(\leftarrow$ stupa $)$, wrótka $(\leftarrow$ wrota $) ;-k o:$ lu-

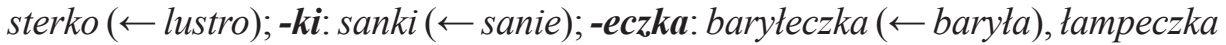
$(\leftarrow$ tampa), taweczka $(\leftarrow$ tawa $)$; -eczki: saneczki $(\leftarrow$ sanie); -oczka: wlannoczka ( $\leftarrow$ wanna $)$; -uszek: garnuszek $(\leftarrow$ garnek); -onek: boczonek $(\leftarrow$ boczka); -inka: szafinka $(\leftarrow s z a f a)$.

Dwa razy w badanej grupie tematycznej pojawił się sufiks -yna: dziższczyna $(\leftarrow d z i e z ̇ k a) ;$ miszczyna $(\leftarrow$ miska).

Wśród czasowników wystapiły derywaty prefiksalne:

na-: napalać, naprząść, narwać, nasiać, nażać;

ob-: obczyniać (też obczynić), obszmorgować, obżynać;

${ }^{6}$ Ukraińskiego sufiksu -ok nie odnotowano. 
po-: pognać, poobrzynać, posadzić, posiekać, postawić, pozbierać;

pro-: prorywać;

roz-: rozsadzać, rozsiewać, roztrzaść;

wy-: wycierać, wyganiać (też wygnać), wykopać, wykosić, wymłócić, wyorać, wyplewić, wyrąbać, wyrwać, wywieść, wyżać;

z- (ze-)//s-: skopać, skosić, zbierać, zebrać, zgartać, zmłócić, zrąbać;

za-: zasiewać.

\section{PODSUMOWANIE}

Wśród wyekscerpowanych 284 wyrazów przeważają wyrazy wspólne- 125 (44\%), wyrazy rodzime stanowią 90 przykładów (32\%), a wyrazy zapożyczone 69 (24\%). W percepcji tekstów ciągłych silnie zaznaczają się zapożyczenia, ale przy analizie słownictwa okazuje się, że słownictwo rodzime, zwłaszcza jeśli dodać do niego wyrazy wspólne, zdecydowanie dominuje.

W zapożyczeniach przeważają ukrainizmy - 51 wyrazów (18\%): banta 'płatew'; boczonek 'mała beczka'; bombetel 'rozkładana sofa'; cebryk 'zdrobn. od ceber'; chacinka 'zdrobn. od chata'; chadziajować 'gospodarować'; chadziajstwo 'gospodarstwo'; chata2 'pokój'; chliw 'chlew'; czeryń 'trzon pieca'; diżka 'dzieżka'; dwery 'drzwi'; dziższczyna 'mała dzieża'; firtka 'furtka'; grabli 'grabie'; hładuszczek 'naczynie gliniane bez ucha'; kaczałka 'wałek do ciasta'; kadubek 'mała beczka'; kastrula 'garnek'; kastrulka 'garnuszek'; kiernica 'studnia'; komirczyna 'spiżarnia'; kopatka 'rodzaj łopaty'; koswa 'kosa'; łeżanka 'miejsce do leżenia na piecu'; makohon 'stępor, thuczek do stępy'; miszczyna 'miska'; miszczynka 'miseczka'; naszczlepluwać 'naszczepiać'; obczyniać 'czyścić buraki z ziemi' (też obczynić 'obczyścić buraki z ziemi'); obszmorgować 'wyrywać, wyciagać'; parynować 'pierwszy raz orać ściernisko'; perełlaz 'przełaz'; pluh 'pług'; pohryb 'piwnica' (z ukr. dial./pot. погриб); posuda 'naczynie'; prorywać 'przerywać'; rondel 'szumówka'; sapak 'motyka'; sapka 'motyka'; sinoklos 'koszenie i suszenie traw'; stołek2 'zdrobn. od stół'; stupka 'zdrobn. od moździerz'; suchowidła 'widły'; swołok 'tragarz, belka pod powałą; szafinka 'szafka na naczynia kuchenne'; ścil 'sufit'; w'ulyky 'ule'; wywarka 'naczynie, w którym gotują szmacia'; zastoronek 'miejsce w stodole dla przechowywania'; żarownia 'patelnia'.

Wyrazy cebryk, chliw, dizka, firtka, płuh, sinokos można by traktować jak wyrazy polskie z wpływem fonetyki ukraińskiej. Podobnie jak wielu badaczy polszczyzny na Ukrainie [np. Rieger, 2019, s. 131-206] uważam, że są to wyrazy ukraińskie.

Zapożyczenia o możliwej proweniencji ukraińskiej i/lub rosyjskiej to 9 wyrazów (3\%): bałka 'belka'; bałklon 'balkon'; czerepica 'dachówka'; diwan 'sofa'; 
krużka 'kubek'; tampa; stójło 'miejsce w chlewie, gdzie stoi bydło'; szyfier 'szyfer, łupek'; w'annoczka 'wanienka'.

Rusycyzmów jest 9 (3\%): kładowka 'spiżarnia', klomnata 'izba, pokój', kosiłka 'kosiarka', młóciłka 'młocarnia', mołotiłka 'młocarnia', stolik 'zdrobn. od stół', szkaf 'szafa', witka 'widelec', zablor 'ogrodzenie'.

Rozpowszechnienie się zapożyczeń staje się procesem naturalnym, ponieważ języka ukraińskiego coraz częściej używa się we wszystkich sferach życia codziennego. Współistnienie języków wyraźnie ilustruje także 31 par/szeregów synonimicznych, składających się z wyrazów rodzimych/wspólnych (12), wyrazów rodzimych/wspólnych i zapożyczeń (17), zapożyczeń (2). Ich obecność świadczy zarówno o nasyceniu miejscowej polszczyzny wpływami obcymi, jak i o jej bronieniu się przed nimi.

Charakterystyczne dla słownictwa związanego z gospodarstwem jest użycie wyrazów zdrobniałych (42 wyrazy - 15\%), które tworzone są za pomocą sufiksów: -ek, -yk, -ik, -ka, -ko, -ki, -eczka, -eczki, -oczka, -uszek, -onek, -inka.

$\mathrm{W}$ prefiksacji biorą udział formanty przedrostkowe przeważnie charakterystyczne dla języka ogólnopolskiego: $n a_{-}^{-}, o b-, p o-^{-}, r o z_{-}, w y-, z_{-}\left(z e_{-}^{-}\right) / / s^{-}, z a^{-}$. Odnotowałam sufiks pro-, używany pod wpływem języka ukraińskiego.

\section{ROZWIAZZANIA SKRÓTÓW}

Skróty konwencjonalne

$$
\begin{array}{ll}
\text { dial. } & \text { - dialektalny } \\
\text { gwar. } & - \text { gwarowy } \\
\text { pol. } & - \text { polski } \\
\text { por. } & - \text { porównaj } \\
\text { pot. } & - \text { potoczny } \\
\text { ros. } & - \text { rosyjski } \\
\text { ukr. } & - \text { ukraiński } \\
\text { zdrobn. } & \text { - zdrobnienie }
\end{array}
$$

\section{Słowniki}

SGM - Wronicz Jadwiga, red., 2016-2017, Stownik gwar małopolskich, t. I-II, Instytut Języka Polskiego Polskiej Akademii Nauk, Kraków.

SHr - HrinczenKo Borys, 1907-1908, Stowar' ukrajins'koji mowy, t. I-IV, Wydawnyctwo Ukrajins'ke słowo, Kyjiw. 
SJPD - Doroszewski Witold, red., 1958-1969, Stownik języka polskiego, t. I-XI, Wiedza Powszechna, Warszawa.

SL - Linde Samuel Bogumił, 1807-1814, Słownik języka polskiego, t. I-VI, Drukarnia XX. Pijarów, Warszawa.

SPH - BRYLIns'KYJ Dmytro, 1991, Stownykpodil's'kych howirok, Redakcijno-wydawnyczyj widdił, Chmel'nyc'kyj.

SPXVI - MAYENowa Maria Renata, red., 1966-2011, Stownik polszczyzny XVI wieku, t. I-XXXV, Instytut Badań Literackich Polskiej Akademii Nauk, Wrocław.

SUM - BIŁOdID Iwan, red., 1970-1980, Stownyk ukrajins'koji mowy w 11 t., Naukowa dumka, Kyjiw, http://sum.in.ua/s/sum (dostęp: 8.11.2019).

SW - KarŁowicz Jan, KryŃski Adam Antoni, NiedźwiedzKi Władysław, red., 1900-1927, Słownik języka polskiego, t. 1-8, Państwowy Instytut Wydawniczy, Warszawa.

TSRJ - OżEgow Sergej, Szwedowa Natalija, 2006, Tołkowyj stowar' russkogo jazyka, Technologii, Moskwa.

\section{BIBLIOGRAFIA}

BARTMIŃSKI Jerzy, BielińSKA-GARDZIEL Iwona, 2012, Polski językowo-kulturowy obraz doтu (cz. I), w: M. Abramowicz, J. Bartmiński, I. Bielińska-Gardziel, Wartości w językowo-kulturowym obrazie świata Stowian i ich sąsiadów, t. 1, Wydawnictwo Uniwersytetu Marii Curie-Skłodowskiej, Lublin, s. 9-46.

CHERNIAK Viktoriia, w druku, Świat roślin w gwarze wsi Wójtowce na Podolu na tle innych gwar polskich na Ukrainie, w: E. Solak, B. Todorović, B. Popiołek, red., Stowiańskie przyjemności 3: Wielojęzyczność, Kraków.

Dejna Karol, 1987, Atlas gwar polskich. Kwestionariusz - notatnik, Zakład Poligraficzny Politechniki Łódzkiej, Łódź.

DzIĘGIEl Ewa, 2003, Polszczyzna na Ukrainie. Sytuacja językowa w wybranych wsiach polskich $i$ szlacheckich, Wydawnictwo Naukowe Semper, Warszawa.

Karaś Halina, 1996, Rusycyzmy stownikowe w polszczyźnie okresu zaborów, Dom Wydawniczy Elipsa, Warszawa.

KozŁowsKa-Doda Jadwiga, 2015, Paniacce „,dom” u suczasnaj biełaruskaj mowie, Wydawnictwo Uniwersytetu Marii Curie-Skłodowskiej, Lublin.

KRAWCZYK Aleksandra, 2007, Zapożyczenia leksykalne w sytuacji wielojęzyczności. Ukrainizmy i rusycyzmy w gwarze Maćkowiec na Podolu, Wydawnictwo DiG, Warszawa. 
MisiaK Małgorzata, 2015, Językowy obraz DOMU w etnolekcie temkowskim. Analiza danych słownikowych, w: J. Konickaja, red., Slavistica Vilnensis, Vilniaus Universitetas, Vilnius, s. 61-73.

Nepop Lidija, 2004, Łeksyczni osobływosti pol's'kych howirok na terytoriji Chmiel'nyc'koji ta Żytomyrs'koji obłastej, Wydawnyczo-poligraficznyj centr „Kyjiws'kyj uniwersytet”, Kyjiw.

Rieger Janusz, 2019, Język polski na Kresach, Wydawnictwo DiG, Warszawa.

TORCZYns'Ka Natalija, TorCZYns'KY Mychajło, 2008, Stownyk wtasnych geograficznych nazw Chmiel'nyckoji obłasti, Awist, Chmel'nyc'kyj.

Tymbrowska Genowefa, Stownictwo mieszkańców Czerwonych Chatek wedtug kwestionariusza Atlasu gwar polskich [komputeropis].

WaLCZAK Bogdan, 1982, Z zagadnień etymologizacji zapożyczeń romańskich w języku polskim, w: J. Tokarski, red., Język. Teoria - dydaktyka. Materiały $V$ konferencji Młodych Językoznawców - Dydaktyków, Wyższa Szkoła Pedagogiczna im. Jana Kochanowskiego, Kielce, s. 172-194.

ZakhUtska Oksana, 2015, Polszczyzna drobnoszlacheckiej wsi Siaberka na Wotyniu. Stownictwo, Wydawnictwo DiG, Warszawa.

Zielińska Anna, 2013, Mowa pogranicza. Studium o językach i tożsamościach w regionie lubuskim, Instytut Slawistyki Polskiej Akademii Nauk, Warszawa.

\title{
Viktoriia Cherniak
}

\section{DOM I ZABUDOWANIA GOSPODARSKIE W POLSKIEJ GWARZE WSI WÓJTOWCE NA PODOLU}

\begin{abstract}
Streszczenie
W artykule przedstawiono słownictwo związane z domem mieszkalnym, zabudowaniami gospodarskimi, a także z ich wyposażeniem (284 wyrazy). Wyrazy zostały podzielone na pięć grup tematycznych (w niektórych wydzielono podgrupy): określenia domu i jego elementów (47 wyrazów), sprzęty i wyposażenie ( 87 wyrazów), zabudowania gospodarskie (43 wyrazy), sprzęty i narzędzia gospodarskie (46 wyrazów), czynności związane z pracą w gospodarstwie (61 wyrazów). Przeważają tu wyrazy wspólne - 125 (44\%), wyrazy rodzime stanowią 90 przykładów (32\%), wyrazy zapożyczone 69 (24\%). Przedstawiono także 31 par/szeregów synonimicznych, składających się z wyrazów rodzimych/wspólnych i wyrazów zapożyczonych oraz uwagi o słowotwórstwie.
\end{abstract}




\title{
HOUSE AND FARM BUILDINGS IN POLISH DIALECT IN THE VILLAGE OF WÓJTOWCE IN PODOLIA
}

\begin{abstract}
Summary
This article presents vocabulary related to residential house, farm buildings and also with their associated objects ( 284 words). The material is divided into 5 thematic groups (subgroups are separated in some of them): house definition (specification) and its elements (47 words), equipment and articles ( 87 words), farm buildings ( 43 words), household equipment and tools ( 46 words), actions connected with work in the household ( 61 words). The analysis of vocabulary shows that common words form the largest group - 127 (45\%), while native Polish words constitute 90 lexemes (32\%), Ukrainian and/or Russian borrowings - 67 (23\%). Synonymic pairs which consist of native Polish words/common words and Ukrainian and/or Russian borrowings are also shown. Notes about word formation are also provided.
\end{abstract}

